\title{
Next-generation LTR-specific Tre-recombinase targets a majority of HIV-1 isolates
}

\author{
Joachim Hauber ${ }^{1 *}$, Janet Karpinski ${ }^{2}$, Ilona Hauber ${ }^{1}$, Jan Chemnitz ${ }^{1}$, Helga Hofmann-Sieber ${ }^{1}$, Claus-Henning Nagel $^{1}$, \\ Niklas Beschorner ${ }^{1}$, Carola Schäfer ${ }^{1}$, Frank Buchholz ${ }^{2}$ \\ From International Symposium HIV and Emerging Infectious Diseases 2014 \\ Marseille, France. 21-23 May 2013
}

\section{Introduction}

HIV-1 integrates into the host chromosome and persists as a provirus flanked by long terminal repeats (LTR). To date, treatment regimens primarily target the virus enzymes, virus attachment or virus-cell fusion, but not the integrated provirus. Thus, current antiretroviral therapies (i.e. cART) cannot eradicate HIV-1, a fact that highlights the urgency of pursuing new strategies to find a cure for HIV/AIDS.

Previously, we engineered an experimental LTR-specific recombinase (Tre-recombinase) that can effectively excise integrated HIV-1 proviral DNA from infected human cell cultures (Sarkar et al. 2007 Science 316:1912). Subsequently, we demonstrated highly significant antiviral activity of this HIV-1 subtype A-specific Tre in humanized mice (Hauber et al. 2013 PLOS pathogens 9:e1003587). Broad clinical application, however, requires availability of a tre-recombinase that recognizes a majority of clinical HIV-1 isolates.

\section{Materials and methods}

Here we report LTR target site identification as well as the engineering and functional analysis of a next-generation Tre-recombinase that recognizes the vast majority (e.g. $>93 \%$ clade B and $>80 \%$ clade A) of clinical HIV-1 isolates.

\section{Results}

It is shown that the HIV-1 LTR harbours a conserved region that may serve as a universal tre recognition site for provirus excision. In fact, targeting this site by nextgeneration tre-recombinase demonstrates pronounced antiviral activity in the absence of cellular toxicity.

${ }^{1}$ Heinrich Pette Institute, Leibniz Institute for Experimental Virology, Hamburg, Germany

Full list of author information is available at the end of the article

\section{Conclusion}

The presented data suggest that next-generation Tre technology may be a valuable component of future antiretroviral therapies to reverse infection and thereby providing a cure for HIV/AIDS.

\section{Authors' details \\ 'Heinrich Pette Institute, Leibniz Institute for Experimental Virology, Hamburg, Germany. ${ }^{2}$ University of Technology Dresden, University Hospital and Medical Faculty Carl Gustav Carus, Department of Medical Systems Biology, Dresden, Germany.}

Published: 23 May 2014

doi:10.1186/1471-2334-14-S2-018

Cite this article as: Hauber et al:: Next-generation LTR-specific Trerecombinase targets a majority of HIV-1 isolates. BMC Infectious Diseases 2014 14(Suppl 2):018.
Submit your next manuscript to BioMed Central and take full advantage of:

- Convenient online submission

- Thorough peer review

- No space constraints or color figure charges

- Immediate publication on acceptance

- Inclusion in PubMed, CAS, Scopus and Google Scholar

- Research which is freely available for redistribution

Submit your manuscript at www.biomedcentral.com/submit
() Biomed Central 